\title{
Effects of dietary bamboo charcoal powder including vinegar liquid on chicken performance and histological alterations of intestine
}

\author{
K. Yamauchi ${ }^{1,3}$, J. Ruttanavut ${ }^{1}$ and S. Takenoyama ${ }^{2}$ \\ ${ }^{1}$ Laboratory of Animal Science, Faculty of Agriculture, Kagawa University \\ Miki-cho, Kagawa-ken 761-0795, Japan \\ ${ }^{2}$ Department of Nutrition Management, Faculty of Health and Nutrition, \\ Minami-Kyusyu University \\ Kirishima, Miyazaki-ken 880-0032, Japan
}

(Received 31 March 2009; revised version 17 December 2009; accepted 9 May 2010)

\begin{abstract}
Forty-eight 154-d-old White Leghorn hens were fed a diet containing 0 (control), 0.5, 1.0 and $1.5 \%$ bamboo charcoal powder including vinegar liquid (SB). Compared with the control group, production performance in the SB groups did not differ. Egg production tended to be increased in the 0.5 and $1.0 \% \mathrm{SB}$ groups, but decreased in the $1.5 \% \mathrm{SB}$ group; the former two groups were higher than the latter $(\mathrm{P}<0.05)$. The SB groups showed a lower level of faecal ammonia gas and a higher level of polyphenol in the egg yolk, but the differences were not statistically significant. The intestinal villus height, cell area, and cell mitosis number tended to be higher in the SB groups. Duodenal cell mitosis was increased in all SB groups $(\mathrm{P}<0.05)$. The control group showed flat cells on the villus apical surface, while the SB groups showed protuberated cells. The present results indicate stimulating effects of dietary SB on intestinal villi and structure of epithelial cells and the 0.5 and $1.0 \%$ levels improved production performance. These suggest that the SB can be supplemented until a level of $1.0 \%$.
\end{abstract}

KEY WORDS: bamboo charcoal powder, bamboo vinegar liquid, villi, histological intestinal alterations, chicken

\footnotetext{
${ }^{3}$ Corresponding author: e-mail: yamauchi@ag.kagawa-u.ac.jp
} 


\section{INTRODUCTION}

Antibiotics have been extensively used in poultry diets to maintain health and production efficiency. However, because of the development of resistance by pathogenic bacteria, antibiotics were withdrawn from poultry diets around the world. Therefore, finding alternative ways to replace antibiotics is necessary. A possible alternative to antibiotics for growth promotion and feed efficiency improvement in domestic avian species is to use natural substances stimulating the intestinal function. Bamboo charcoal is known as a universal adsorbent, because it contains a complex network of pores of various shapes and sizes (Zhao et al., 2008). Its powder has been used as an oral antidote to reduce the absorption of poison from the gastrointestinal tract (Anjaneyulu et al., 1993). Another alternative may be bamboo vinegar compound liquid which is obtained after cooling smoke during manufacturing of bamboo charcoal. It is believed that bamboo vinegar can act as insecticide, a bactericide, a deodorant for treating malodour from pets, and also as a folk medicine (Akakabe et al., 2006). The main component of bamboo vinegar compound liquid is acetic acid. Acetic acid was reported to inhibit growth of pathogenic bacteria and to accelerate growth of beneficial bacteria (Watarai and Tana, 2005). Recently, a mixed powder (Super BOB ${ }^{\circledR}, \mathrm{SB}$ ) of bamboo charcoal (includes $733 \mathrm{mg} / 100 \mathrm{~g}$ polyphenol) and bamboo vinegar compound liquid (includes $1535 \mathrm{mg} / 100 \mathrm{~g}$ polyphenol) has been produced in Japan for supplementation to animal feed. However, no production performance of animals fed SB has yet been investigated. Polyphenols are known to have antioxidant function and to prevent cell aging by effectively removing excess active oxygen species. As the differentiation of superior egg quality becomes popular, it was thus of great interest to investigate the possibility that SB could elevate polyphenol level in egg. Since the small intestine is the site of nutritional absorption from the intestinal lumen through the mucosal epithelial cells into the blood or lymphatic system, and as the histological alterations of the intestinal villi and epithelial cells on the villus apical surface are known to be affected by dietary feed components (Langhout et al., 1999; Yasar and Forbes, 1999), supplementing dietary SB may affect intestinal function.

The objective of this experiment was to study the effects of dietary SB on production performance, level of polyphenol in egg yolk and faecal ammonia gas level. Subsequently, the villus height, cell area and cell mitosis number in each intestinal segment of these birds were observed using light microscopy. Additionally, epithelial cell alterations of the villus tip surface were compared using scanning electron microscopy. 


\section{MATERIAL AND METHODS}

The birds and the design of the experiment

A total of 48 of 119-d-old Single Comb White Leghorn hens (Gallus gallus domesticus; Julia strain) were obtained from a commercial farm and raised in individual cages in an animal house of the Laboratory of Animal Science of Kagawa University until d 153. At the age of 154-d-old, 48 birds were randomly allotted into four dietary treatment groups of similar mean body weight and egg production level, comprising 12 birds each. Standard layer diet (Table 1)

Table 1. Ingredient and chemical composition of the basal commercial finisher mash diets

\begin{tabular}{|c|c|}
\hline Item & $\%$ \\
\hline \multicolumn{2}{|l|}{ Ingredient } \\
\hline ground maize, milo & 62.0 \\
\hline soyabean meal & 25.0 \\
\hline fish meal & 3.0 \\
\hline rice bran & 1.0 \\
\hline concentrate mixture $^{1}$ & 9.9 \\
\hline \multicolumn{2}{|c|}{ Analysed chemical composition of feed } \\
\hline $\mathrm{ME}, \mathrm{MJ} / \mathrm{kg}$ & 11.72 \\
\hline crude protein & 17.0 \\
\hline crude fat & 3.0 \\
\hline crude fibre & 6.0 \\
\hline crude ash & 12.5 \\
\hline calcium & 2.6 \\
\hline phosphorus & 0.5 \\
\hline
\end{tabular}

obtained from commercial feed company (Nippon Formula Feed MFG. Co., Ltd., Kanagawa, Japan) was used as a basal feed supplemented with SB at 0, 0.5, 1.0 and $1.5 \%$. Commercial $\mathrm{SB}{ }^{\circledR}$ was produced in the company (Super BOB ${ }^{\circledR}$, Shikoku Tekuno Co., Ltd., Kagawa, Japan) by as follows: bamboo vinegar compound liquid (Table 2) obtained after cooling smoke during making bambo charcoal (Table 3) from moso bamboo (Phyllostachys pubescens) by dry distillation at $700^{\circ} \mathrm{C}$ was kept for one year. Then, the skimmed solution was distilled to remove harmful substances such as tar. This bamboo vinegar compounds were absorbed into bamboo charcoal powder (3:8). Water and the respective experimental diets for 33 weeks (until 389-d-old) were provided ad libitum. From 154 to 273 days of age, feed intake, body weight, egg production and egg weight were measured weekly. 
Table 2. Composition of bamboo vinegar compound solution

\begin{tabular}{ll}
\hline Item & $\%$ \\
\hline Acidity & 2.90 \\
Total organic carbon & 2.38 \\
Acetic acid & 2.72 \\
Phosphate & 0.10 \\
Methanol & 0.07 \\
Formaldehyde & 0.003 \\
Phenol & 0.134 \\
Cresol & 0.051 \\
Tar & 1.10 \\
pH & 2.7 \\
\hline
\end{tabular}

Table 3. Composition of bamboo charcoal powder

\begin{tabular}{lc}
\hline Item & $\%$ \\
\hline Ash & 6.35 \\
Nitrogen & 0.57 \\
Phosphate & 1.06 \\
Potassium & 2.10 \\
Silicon dioxide & 1.20 \\
pH & 10.20 \\
\hline
\end{tabular}

All experiments were carried out according to the Human Care Guidelines for the Care and Use of Laboratory Animals established by the Rules of Animal Experiment in Kagawa University.

\section{Odour emission}

The emission of odour from the chickens' faeces was weekly measured from 154 to 245 days of age. To collect the fresh faeces from each of 5 birds per group, plastic boxes were set under the individual cages of each hen overnight. The collected fresh faeces were transferred to a vinyl bag and blended to obtain a homogeneous mass of faeces, a $30 \mathrm{~g}$ sample of which was transferred to a plastic box with a lid. The plastic box was kept in an incubator at $37^{\circ} \mathrm{C}$ for one $\mathrm{h}$, then left in the room for $30 \mathrm{~min}$. The odour emission of the faeces was measured at room temperature using a small portable sensor (XP-329N, Osaka, Japan) for ammonia gas. The tube of the sensor was inserted into the capped box, and the maximum values were recorded.

Polyphenol in egg yolk

Seven hens were randomly selected from each group, and the polyphenol in 
each egg yolk was measured at the age of 245, 252, 259, 266 and $273 \mathrm{~d}$. The polyphenol in the egg yolk was determined according to the Folin-Denis method (Tsushida, 2000). The polyphenol was extracted from the boiled egg yolk using $10 \mathrm{ml}$ of $80 \%$ ethanol solution per $1 \mathrm{~g}$ of egg yolk. For this extracted polyphenol of $0.2 \mathrm{ml}, 3.6 \mathrm{ml}$ water, $0.2 \mathrm{ml}$ Folin-Denis reagent, and $0.4 \mathrm{ml}$ saturated sodium carbonate solution were added, and reacted $30 \mathrm{~min}$. After removing the impurity by centrifuging ( $3000 \mathrm{rpm}, 5 \mathrm{~min}$ ), the absorbance ( $760 \mathrm{~nm}$ wavelength) was measured, calculated from the standard curve in a catechin solution.

\section{Tissue sampling}

At 347 and $389 \mathrm{~d}$ of age (at the end of feeding experimental period), 2 birds showing average body weight were selected from each group each day for observing histological alterations of intestine. Hens under light anaesthesia with diethyl ether were killed by decapitation. The histological intestinal preparation method was performed in a similar manner as described in a previous report (Yamauchi et al., 2006). Briefly, the duodenal, jejunal, and ileal parts for light microscopy were fixed in Bouin's fixative solution, embedded in paraplast, cut at five-micrometerthick transverse sections, and stained with haematoxylin-eosin.

\section{Light microscopy}

Villus height and cell area were measured using an image analyzer (Nikon Labophot-2, Tokyo, Japan). For villus height, the two longest villi having a lamina propria were measured per transverse section. A total of 16 villi were counted from different sections in each bird. An average of these 16 villi was expressed as the mean villus height for each bird. The area of the epithelial cell layer was randomly measured, and then the cell nuclei within this measured cell layer were counted. Finally, the area of the layer was divided by the number of cell nuclei. A total of 16 samples per bird were counted in each group. Mitotic cells having homogenous, intensely stained basophilic nuclei with haematoxylin (Tarachai and Yamauchi, 2000) were counted. In the case of cells in the late stages of division, the cell mitosis number was counted as one mitotic event. Total mitosis numbers were counted from 4 different sections for each bird, and these 4 values were used to calculate the mean for one bird. Finally, these 4 mean values of villus height, cell area, and mitotic cells from the 4 birds were expressed as a single mean light microscopic parameter for one treatment group. 


\section{Scanning electron microscopy}

Each intestinal segment was fixed in a mixture of 3\% glutaraldehyde and 4\% paraformaldehyde fixative solution in $0.1 \mathrm{M}$ carcodylate buffer ( $\mathrm{pH} 7.4$ ), dehydrated in $45-80 \%$ graded ethanol solutions, and kept in $80 \%$ ethanol. Just before the specimens were dried, they were moved to $90-100 \%$ graded solutions (each, 15 $\mathrm{min}$ ), followed by a mixed solution of $100 \%$ ethanol and t-butyl alcohol (15 min), and t-butyl alcohol (15 min, two times). Then these specimens were dried in a drying apparatus (Hitachi Freeze Dryer, Tokyo, Japan). The dried specimens were mounted on aluminium stubs with electrically conducting carbon paste and sputter coated with platinum (Hitachi E-1030 Ion Sputter, Hitachi Ltd., Tokyo, Japan). Then epithelial cells on the villus tip surface were examined with a scanning electron microscope (Hitachi S-4300SE/N, Hitachi Ltd., Tokyo, Japan) at $8 \mathrm{kV}$.

Statistical analysis

All data were statistically analysed using one-way ANOVA, and significant differences among the treatments were determined with Duncan's Multiple Range Test using the Stat View programme (Abacus Concepts, Inc., HULINKS, Inc., Tokyo, Japan) at a level of $\mathrm{P}<0.05$.

\section{RESULTS}

Table 4 shows the growth and egg production performance in hens fed $0,0.5$, 1.0 , and $1.5 \%$ dietary SB. Compared with the control group, feed intake, body

Table 4. Effects of dietary bamboo charcoal powder including vinegar liquid (SB) on laying performance $($ mean $\pm \mathrm{SE})$

\begin{tabular}{|c|c|c|c|c|}
\hline \multirow{2}{*}{ Item } & \multicolumn{4}{|c|}{ Dietary SB, \% } \\
\hline & 0 & 0.5 & 1.0 & 1.5 \\
\hline $\begin{array}{l}\text { Body weight gain (BWG), } \\
\text { kg/bird); } n=12\end{array}$ & $0.403 \pm 0.04$ & $0.416 \pm 0.04$ & $0.373 \pm 0.04$ & $0.372 \pm 0.05$ \\
\hline Feed intake, FI; kg/bird; $n=12$ & $12.26 \pm 0.10$ & $13.02 \pm 0.10$ & $12.64 \pm 0.12$ & $11.87 \pm 0.12$ \\
\hline Feed efficiency, BWG/FI; n=12 & $0.032 \pm 0.002$ & $0.032 \pm 0.002$ & $0.029 \pm 0.002$ & $0.031 \pm 0.002$ \\
\hline $\begin{array}{l}\text { Total egg production, TEP; } \\
\text { kg/bird; } n=12\end{array}$ & $6.38 \pm 37.00^{\mathrm{ab}}$ & $6.69 \pm 35.68^{a}$ & $6.45 \pm 38.81^{\mathrm{a}}$ & $5.94 \pm 42.75^{\mathrm{b}}$ \\
\hline Feed efficiency, TEP/FI; $n=12$ & $0.525 \pm 0.05$ & $0.518 \pm 0.05$ & $0.516 \pm 0.05$ & $0.506 \pm 0.05$ \\
\hline $\begin{array}{l}\text { Hen house egg production, } \\
\quad \% ; n=12\end{array}$ & $92.34 \pm 0.88^{\mathrm{ab}}$ & $95.80 \pm 0.67^{\mathrm{a}}$ & $93.85 \pm 1.45^{\mathrm{a}}$ & $89.54 \pm 1.19^{b}$ \\
\hline Mean egg weight, g/bird; $n=12$ & $58.99 \pm 1.01$ & $59.32 \pm 1.01$ & $58.51 \pm 1.05$ & $56.61 \pm 1.01$ \\
\hline Ammonia gas, ppm; $\mathrm{n}=5$ & $24.12 \pm 1.80$ & $20.66 \pm 2.05$ & $20.25 \pm 1.92$ & $20.97 \pm 2.36$ \\
\hline Polyphenol, $\mathrm{mg} / 100 \mathrm{~g} ; \mathrm{n}=7$ & $31.87 \pm 0.23$ & $32.15 \pm 0.55$ & $33.38 \pm 0.55$ & $33.41 \pm 0.63$ \\
\hline
\end{tabular}


weight gain and feed efficiency (both of body weight gain and total egg production/feed intake), and mean egg weight were not different. Total egg production and hen-house egg production tended to be higher in the 0.5 and $1.0 \% \mathrm{SB}$ groups, but lower in the $1.5 \% \mathrm{SB}$ group; the former was higher than the latter $(\mathrm{P}<0.05)$. All SB groups showed a lower value of faecal ammonia gas, but a higher value of polyphenol in egg yolk, although these amounts were not significant.

Light microscopic observations. The villus height of the SB groups tended to be increased, except in the $1.5 \% \mathrm{SB}$ group in the jejunum and ileum (Figure 1).

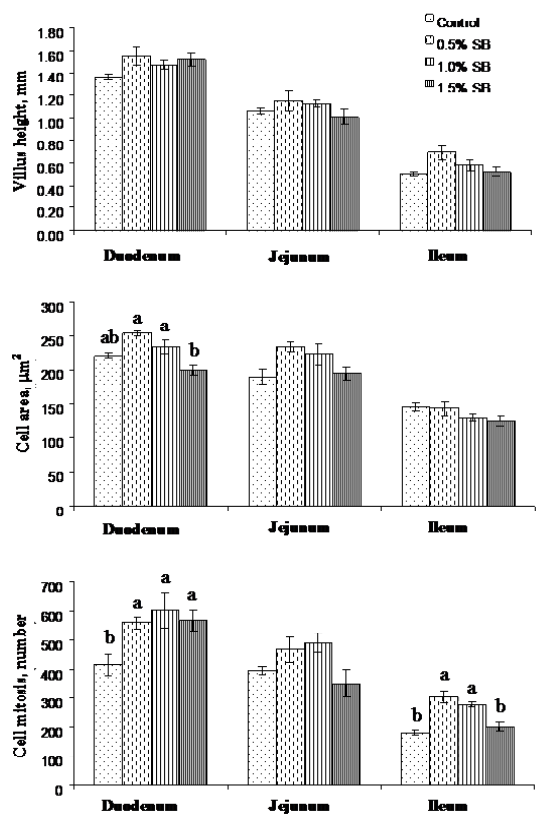

Figure 1. Villus height, cell area, and cell mitosis number in each intestinal segment of chickens fed $0,0.5,1.0$ and $1.5 \%$ dietary bamboo charcoal powder including vinegar liquid $(\mathrm{SB})(\mathrm{n}=4$, mean $\pm \mathrm{SE})$. a,b means with different superscripts are significantly different from each other $(\mathrm{P}<0.05)$

The cell area of the 0.5 and $1.0 \%$ SB groups tended to be increased in the duodenum and jejunum, but did not show any difference in the ileum. Cell mitosis in the 0.5 and $1.0 \%$ SB groups tended to be increased in all intestinal parts, and significantly increased in the duodenum and ileum $(\mathrm{P}<0.05)$. However, cell mitosis in the $1.5 \%$ SB group was higher in the duodenum than in the control $(\mathrm{P}<0.05)$, but was not different in the jejunum and ileum. 
Scanning electron microscopic observations. On the villus apical surface of the control duodenum (Figure 2A), flat cells (arrows) were observed. In all SB groups (Figure 2B-D), cells protuberating farther into the intestinal lumen (arrows) than those of the control group were found.

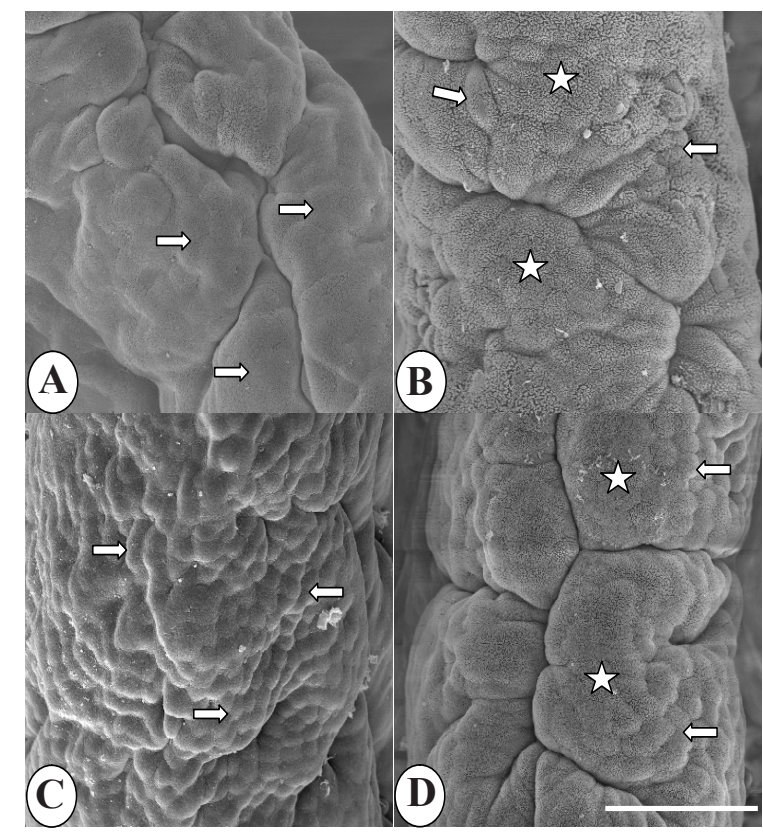

Figure 2. Duodenal villus apical surface of chickens fed $0 \%$ (A; arrows, flat cell area), $0.5 \%$ (B; arrows, protuberating cells; stars, less densely distributed microvilli), $1.0 \%(\mathrm{C}$; arrows, protuberating cells), and $1.5 \%$ (D; arrows, protuberating cells; stars, less densely distributed microvilli) dietary bamboo charcoal powder including vinegar liquid. Scale bar $=50 \mu \mathrm{m}$

In particular, the microvilli of the 0.5 and $1.5 \% \mathrm{SB}$ groups were less densely distributed on cells (stars). On the villus apical surface of the control jejunum (Figure 3A), protuberated cells were found more frequently (arrows) than in the control duodenum. In the SB groups (Figure 3B-D), the villus apical surface of the 0.5 and $1.5 \% \mathrm{SB}$ groups showed morphology similar to the control, such as protuberated cells (arrows). However, the $1.0 \% \mathrm{SB}$ group had many clearly protuberated cells (arrows). On the villus apical surface of the control ileum (Figure 4A), again, flat cells were observed (arrows). In all SB groups (Figure 4B-D), many protuberated cells were observed (arrows). In addition, segmented filamentous bacteria (arrows with B) were present in the 1.0\% SB group. 


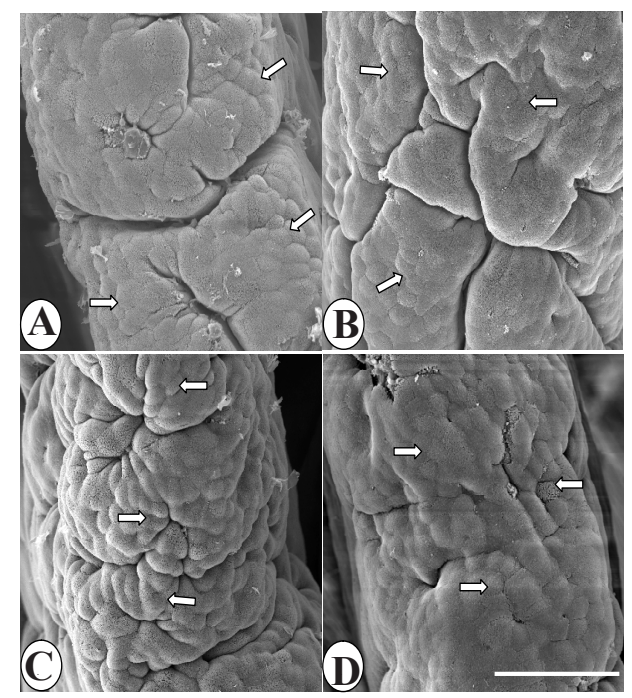

Figure 3. Jejunal villus apical surface of chickens fed $0 \%$ (A; arrows, faintly protuberated cells), $0.5 \%$ (B; arrows, faintly protuberated cells), $1.0 \%$ (C; arrows, protuberating cells), and $1.5 \%$ (D; arrows, faintly protuberated cells) dietary bamboo charcoal powder including vinegar liquid. Scale bar $=50 \mu \mathrm{m}$

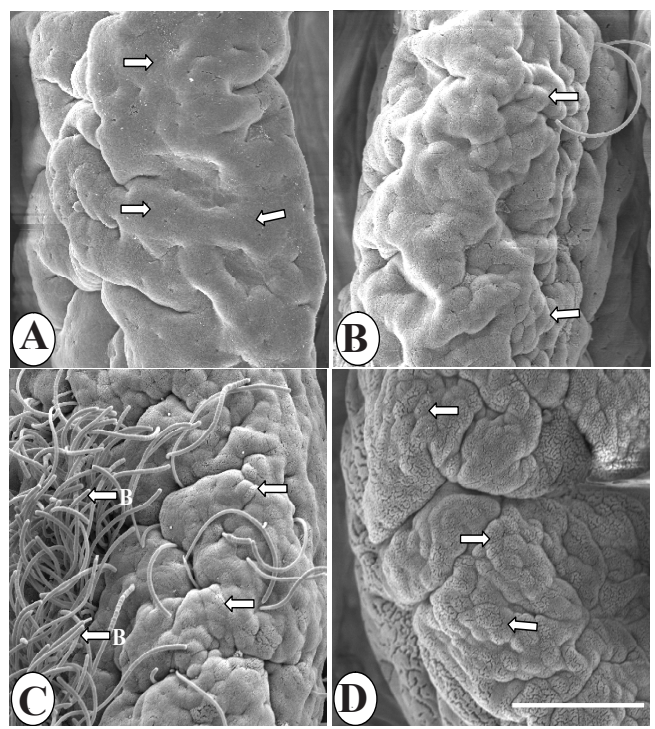

Figure 4. Ileal villus apical surface of chickens fed $0 \%$ (A; arrows, flat cell area), $0.5 \%$ (B; arrows, protuberating cells), $1.0 \%$ (C; arrows, protuberating cells; arrows with $\mathrm{B}$, segmented filamentous bacteria), and $1.5 \%(\mathrm{D}$; arrows, protuberating cells) dietary bamboo charcoal powder including vinegar liquid. Scale bar $=50 \mu \mathrm{m}$ 


\section{DISCUSSION}

In our previous study, the addition of wood charcoal powder including vinegar liquid improved body weight gain in chickens (Samanya and Yamauchi, 2001) and piglets (Mekbungwan et al., 2004) by activating intestinal villi and epithelial cells. This might be induced by both influences of wood charcoal and wood vinegar compound liquid. Bamboo charcoal was reported to have a higher adsorption capacity than wood charcoal, because of the special micro-pore structure of bamboo stems (ChungPin et al., 2004). Bamboo charcoal is known to have about 4 times more cavities, 3 times more mineral content and 4 times better absorption rate (Zhao et al., 2008). Goats fed a diet containing $0.5 \mathrm{~g}$ of bamboo charcoal per $\mathrm{kg}$ of body weight grew faster than the controls (Van et al., 2006). On the other hand, acetic acid is also main component of bamboo vinegar liquid. Acetic acid is one of the main short chain fatty acids produced by intestinal microbes, which can affect intestinal functions and metabolism (Lutz and Scharrer, 1991). Acetic acids were also reported to control the balance of intestinal microflora and pathogen (Sorrells and Speck, 1970). In this study, chickens fed SB did not show an increase in body weight, but tended to show an increase in egg production in the 0.5 and $1.0 \% \mathrm{SB}$ groups. This fact seems to match theoretically, as White Leghorn hens have been genetically modified for improved egg production. Particularly in the $0.5 \% \mathrm{SB}$ group, total egg production showed a $4.8 \%$ increase over the control. Adversely, faecal ammonia gas values were lower in all SB groups. This corresponds with results showing that bamboo charcoal removed odourants such as ammonia, indole and skatole contained in the excreta of animals (Asada et al., 2002). The present faecal ammonia gas is also thought to be adsorbed by the many pores in SB. On the other hand, polyphenol was elevated in all SB groups. The measurement of polyphenol in egg yolk has been described first in this study, because its extraction from the lipids had not been established. The present slight increase of polyphenol in egg yolk is reasonable, because the excessive density of it is harmful due to its functions of antioxidant activity and removing excess active oxygen.

In chickens fed $\mathrm{SB}$, most light microscopic parameters showed higher values in all intestinal segments. It has been suggested that there is a strong correlation between gut structure and feed nutrients, and that villus height can be used to predict weight gain (Pluske et al., 1996). Onderci et al. (2006) suggested that increased height of intestinal villi means a greater surface area for nutrient absorption. Greater villus height and increased cell mitosis numbers in the intestine are indicators of activation of the function of the intestinal villi (Longhout et al., 1999; Yasar and Forbes, 1999). Furthermore, increased villus size was also associated with activated cell proliferation in the crypt (Lauronen et al., 2000), and provided more surface area for nutrient absorption and thus improved nutrient 
provided more surface area for nutrient absorption and thus improved nutrient digestibility (Onderci et al., 2006). In addition to the higher values of light microscopic parameters, protrusion of epithelial cells was frequently observed in the present SB-fed chickens. Such cell protrusion features were also reported in chickens (Yamauchi et al., 2006), Aigamo ducks (a hybrid of the wild duck and domestic duck) (Khambualai et al., 2009), and piglets (Mekbungwan et al., 2008) showing body weight gain. These reports suggest that the higher values of light microscopic parameters and the protrusion of epithelial cells in SB birds would be multiplicatively stimulated by both influences of bamboo charcoal and bamboo vinegar liquid.

\section{CONCLUSIONS}

Histological alterations of intestine in chickens fed the vinegar liquid (SB) diet demonstrate that intestinal function could be stimulated in all intestinal segments, and the 0.5 and $1.0 \%$ levels induced better production performance. The results obtained in this study have confirmed that dietary SB can be used as a natural substance to supplement chicken diets as an alternative to antibiotics.

\section{REFERENCES}

Akakabe Y., Tamura Y., Iwamoto S., Takabayashi M., Nyuugaku T., 2006. Volatile organic compounds with characteristic odor in bamboo vinegar. Biosci. Biotechnol. Biochem. 70, 27972799

Anjaneyulu Y., Rama Rao P., Gopal Naidu N.R., 1993. Experimental aflatoxicosis and its amelioration by activated charcoal in broiler chicken-study on performance and haematology. J. Vet. Anim. Sci. 24, 51-54

Asada T., Ishihara S., Yamane T., Toba A., Yamada A., Oikawa K., 2002. Science of bamboo charcoal: study on carbonizing temperature of bamboo charcoal and removal capability of harmful gases. J. Health Sci. 48, 473-479

ChungPin H., DehJen H., Song Yung W., Ingluen S., Chunhan K., 2004. Effect of carbonization conditions on indoor air purification of bamboo charcoal. Forest Prod. Ind. 23, 183-197

Khambualai O., Ruttanavut J., Kitabatake M., Goto H., Erikawa T., Yamauchi K., 2009. Effects of dietary natural zeolite including plant extract on growth performance and intestinal histology in Aigamo ducks. Brit. Poultry Sci. 50, 123-130

Langhout D.J., Schutte J.B., Van Leeuwen P., Wiebenga J., Tamminga S., 1999. Effect of dietary high and low methyllated citrus pectin on the activity of the ileal microflora and morphology of the small intestinal wall of broiler chickens. Brit. Poultry Sci. 40, 340-347

Lauronen J., Pakarinen M.P., Kuusanmaki P., Savilahti E., Vento P., Paavonen T., Halttunen J., 2000. Intestinal adaptation after massive proximal small bowel resection in the pig. Brit. Poultry Sci. 41, 416-423 
Lutz T., Scharrer E., 1991. Effect of short-chain fatty acids on calcium absorption by the rat colon. Exp. Physiol. 76, 615-618

Mekbungwan A., Yamauchi K., Sakaida T., 2004. Intestinal villus alterations in piglets fed dietary charcoal powder including wood vinegar compound liquid. Anat. Histol. Embryol. 33, 11-16

Mekbungwan A., Yamauchi K., Sakaida T., Buwjoom T., 2008. Effects of a charcoal powder-wood vinegar compound solution in piglets for raw pigeon pea seed meal. Anim. Sci. 3, 366-374

Onderci M., Sahin N., Sahin K., Cikim G., Aydin A., Ozercan I., Aydin S., 2006. Efficacy of supplementation of $\alpha$-amylase-producing bacterial culture on the performance, nutrient use and gut morphology of broiler chickens fed a corn-based diet. Poultry Sci. 85, 505-510

Pluske J.R., Thompson M.J., Atwood C.S., Bird P.H., Willlams I.H., Hartmann P.E., 1996. Maintenance of villus height and crypt depth, and enhancement of disaccharide digestion and monosaccharide absorption, in piglets fed on cows' whole milk after weaning. Brit. J. Nutr. 76, 409-422

Samanya M., Yamauchi K., 2001. Morphological changes of the intestinal villi in chickens fed the dietary charcoal powder including wood vinegar compounds. Jpn. Poultry Sci. 38, 289-301

Sorrells K.M., Speck M.L., 1970. Inhibition of Salmonella gallinarum by culture filtrates of Leuconostoc citrovorum. J. Dairy Sci. 53, 239-241

Watarai S., Tana, 2005. Eliminating the carriage of Salmonella enterica serovar Enteritidis in domestic fowls by feeding activated charcoal from bark containing wood vinegar liquid (NekkaRich). Poultry Sci. 84, 515-521

Tarachai P., Yamauchi K., 2000. Effects of luminal nutrient absorption, intraluminal physical stimulation, and intravenous parenteral alimentation on the recovery responses of duodenal villus morphology following feed withdrawal in chickens. Poultry Sci. 79, 1578-1585

Tsushida T., 2000. Separation and Structural Determination of the Functional Food Component. The Food Function Research Method. Tokyo, pp. 318-322

Van D.T.T., Mui N.T., Ledin I., 2006. Effect of method of processing foliage of Acacia mangium and inclusion of bamboo charcoal in the diet on performance of growing goats. Anim. Feed Sci. Tech. 130, 242-256

Yamauchi K., Buwjoom T., Koge K., Ebashi T., 2006. Histological alterations of the intestinal villi and epithelial cells in chickens fed dietary sugar cane extract. Brit. Poultry Sci. 47, 544-553

Yasar S., Forbes J.M., 1999. Performance and gastro-intestinal response of broiler chicks fed on cereal grain-based foods soaked in water. Brit. Poultry Sci. 40, 65-67

Zhao R., Yuan J., Jiang T., Shi J., Cheng C., 2008. Application of bamboo charcoal as solid-phase extraction adsorbent for the determination of atrazine and simazine in environmental water samples by high-performance liquid chromatography-ultraviolet detector. Talanta 76, 956-959 